\title{
The Construction of a Philosophical Textbook: Some Remarks on Nikephoros Blemmydes' Epitome physica
}

\author{
Stefano Valente \\ University of Hamburg \\ stefano.valente@uni-hamburg.de
}

\begin{abstract}
The Compendium on Physics (Epitome physica) by the Byzantine theologian and philosopher Nikephoros Blemmydes (13th cent.) was a very successful textbook on Natural Philosophy containing a summary of physics, meteorology and astronomy. This compendium was also conceived for being used as support for teaching. For his purposes, Blemmydes combined passages taken from different sources into a new text: Aristotle and his commentators as well as Cleomedes were his main sources. Since a manuscript with an earlier version of the text still survives, it is also possible to go deeper into the workshop of this Byzantine author and to investigate the use of the sources in both textual stages. This paper will therefore be devoted to analysing the inner structure of the Epitome physica and Blemmydes' activity as an author.
\end{abstract}

\section{Keywords}

Nikephoros Blemmydes - Aristotle - Cleomedes - Galen - Byzantine Philosophy

1. Within the Byzantine learning framework, the study of philosophy, and especially of Aristotle, was a core part of the educational process. Besides the direct study of his treatises with the aid of Late Antique and Byzantine commentaries, new didactic works were also produced in order to summarise the contents of his philosophy and to render them more easily accessible. Furthermore, the need to reconcile them with a Christian perspective also played an im-

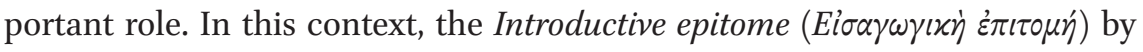
Nikephoros Blemmydes (1197-c. 1269) constitutes probably one of the best and 
most widespread examples of this scholarly practice. ${ }^{1}$ This philosophical textbook in two books on logic and on physics, respectively - customarily known by the Latin name Epitome logica and Epitome physica - was conceived by the author for learning purposes.

The first version of the Epitome dates to the years 1237-1239, when Blemmydes was entrusted by the Emperor John III Doukas Batazes with the education of five young men, one of whom was the later historian George Akropolites. Subsequently, Blemmydes became the teacher of the future Emperor Theodore II Doukas Laskaris. Some Byzantine manuscripts preserve traces of this first redaction, composed by Blemmydes for his teaching duties: for the book on logic, we have the proem ${ }^{2}$ and an excerpt of chs $37-38 ;^{3}$ on the other hand, the second book on physics is transmitted by the ms. Vaticanus gr. 434 (end of 13th century). ${ }^{4}$ During the last years of his life, in the 126os, Blemmydes undertook a thorough revision of his textbook. This operation concerned not only the language and style, but also the structure and the content. The Vatican manuscript is therefore essential for understanding this process. In fact, it offers the rare chance to investigate how a Byzantine author composed and revised a textbook, as if one were looking over his shoulder as he sat at his desk.

2. In order to elucidate the compositional methodology and the purpose of this work, the preface to the Epitome offers valuable insights. ${ }^{5}$ As previously mentioned, this text underwent some sort of revision: in fact, Blemmydes added a dedication to the monks of his monastery to the original proem. This new incipit refers primarily to the part on logic. It reads as follows (688c2-689a4): ${ }^{6}$

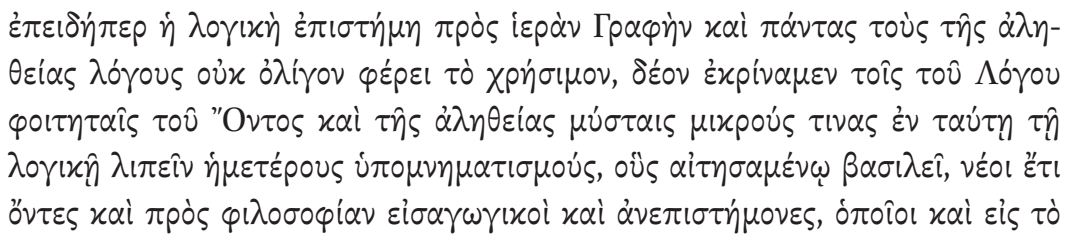

1 On Blemmydes' life and work, see Valente 2018 with further literature. The reference edition for the Epitome is still the editio princeps by Johann Wegelin, published in Augsburg in 1605 and reprinted in vol. 142 of Patrologia Graeca. See also e.g. Lackner 1972; id. 1981; Valente 2017, 232-234.

2 See below, $\S 2$.

3 See Ebbesen 1981, I 330-332, III 82-85; Lackner 1981, 363 with n. 1; Bydén 2003, 28.

4 See Lackner 1981, 353ff.; on this manuscript, see also Devreesse 1937, 162-165; Valente 2017, 233f., id. 2019, 521f. with further literature.

5 On this proem, see also Carelos 2005, 401f.; Paidas 2007.

6 All the quotation from the Introductive epitome refer to $P G 142$ (see above, n. 1). 


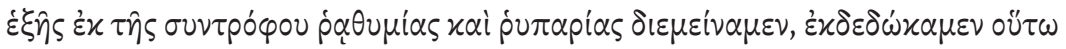

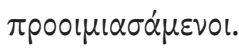

'Since the logical science brings a not small advantage to the Holy Writing and to all the words of truth, ${ }^{7}$ we estimated it necessary to leave some of our treatises concerning this logical science to the disciples of the Logos Who Is and to the initiated into the Truth. As we were still young, newly introduced into the philosophy, ${ }^{8}$ and ignorant - as we have remained in subsequent years due to innate laziness and sordidness -, we published them for the Emperor, on his request. The proem was the following'.

The proem of the first version of the compendium follows. According to a convention, Blemmydes opened it with a celebration of the Emperor's political and philosophical merits. ${ }^{9}$ What is important for the present investigation is that some features of this treatise are mentioned at the end of this text $\left(689 \mathrm{c} 12-\mathrm{d}_{5}\right)$ :

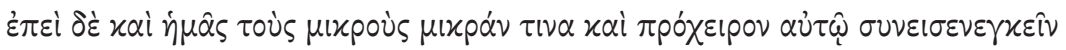

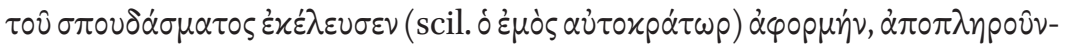

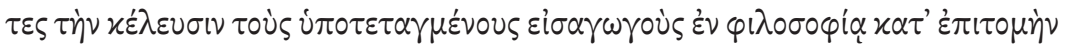

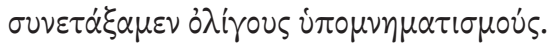

'Since [our Emperor] commissioned a small and accessible subsidiary work even to us, who are of little consequence, we fulfilled his command and composed the following short treatises as an introduction to philosophy, redacted in the form of an epitome'.

Blemmydes composed this work to support his teaching activities, on the re-

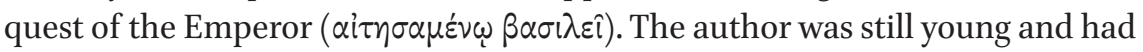

7 Also in his Autobiography, Blemmydes remarks the benefits of logic in religious controversies: see in particular II 67,13-16 Munitiz and, more in general, II 67-74. See also Ierodiakonou 2012.

8 The adjective $\varepsilon i \sigma \alpha \gamma \omega \gamma(x o ́ s$, 'introductive', is peculiar when used to refer to a person, as in this case. Wegelin translates this phrase as follows: cum adhuc ad philosophiam introduceremur.

9 This is the beginning of the first proem (689a5f.; see also Carelos 2005, 401): B $\alpha \sigma i \lambda \varepsilon i \alpha \varsigma$ x $\alpha \mathrm{i}$

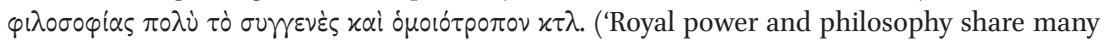
akin and analogous features etc.'). On this proem, see recently Angelov 2012, 37 and, more generally, 34-45. In many manuscripts of the Epitome logica, and especially in the oldest ones, the participle $\pi$ poor $\mu$ l $\sigma \dot{\alpha} \mu \varepsilon v 0$ l that closes the second proem is followed by a strong punctuation mark (':-') and the letter beta in $\beta \alpha \sigma i \lambda \varepsilon i \alpha \varsigma$ is rubricated: see e.g. Monac. gr. 225, fol. $41^{\mathrm{v}}$; Bodl. Holkh. gr. 71, fol. $2^{\mathrm{r}}$ (on these two manuscripts, see Valente 2019, 522f. and $524 f$. with further bibliography). 
recently been introduced to philosophy, as he remarks with a certain under-

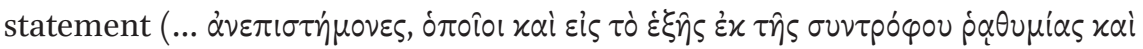

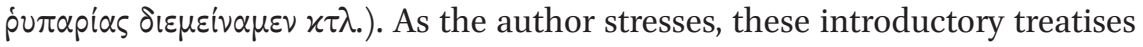
to philosophy (i $\pi \circ \mu \nu \eta \mu \alpha \tau i \sigma \mu o i ́)$ are written in the form of an epitome $\left(\kappa \alpha \tau^{\prime}\right.$

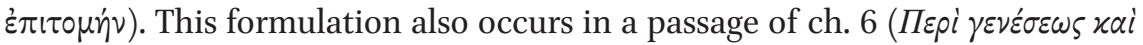
$\varphi \vartheta$ $\vartheta \hat{\alpha}$ s). Roughly in the middle of the chapter, Blemmydes concludes the discussion on generation and corruption in general $(\dot{\alpha} \pi \lambda \hat{\omega} \varsigma)$ with these words (1084b13-15):

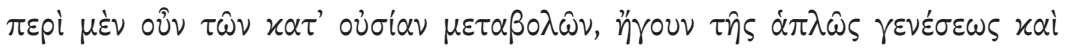

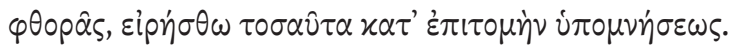

'Thus, let so much be said about the changes in relation to substance, that is in relation to generation and corruption in general, in the form of an epitomized investigation'.

In this case, the source Blemmydes uses in compiling this passage is Simplicius' commentary on Aristotle's Physics (CAG IX 908,15-909,1 Diels). Such an operation of abridging and reshaping the sources is typical of the whole work. ${ }^{10}$ More in general, Blemmydes' goal is to compose a useful textbook for teaching and learning. This intention also emerges from a passage in the second book of his Autobiography, in which Blemmydes resumes his own activity as an author. Here, he lists the treatises he composed during his life, also outlining their content (II 75,1-8 Munitiz):

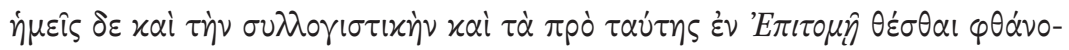

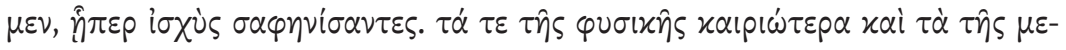

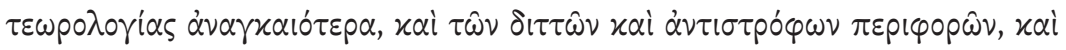

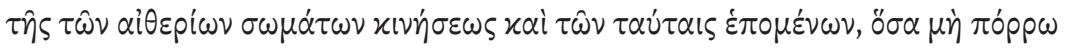

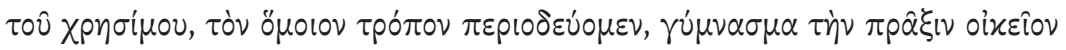
$\pi \circ 100$ น́

'For my part, I set about writing an Epitome of syllogistic and the parts [of logic] that precede it, trying to be as clear as I possibly could. I also described the most important parts of physics and what is basic in 'meteorology', the double revolution in opposite directions, and the other

10 See Valente 2017 with further bibliography. It is also common to other treatises by this au-

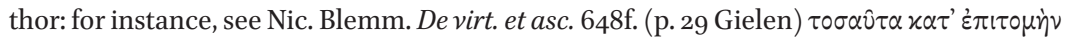

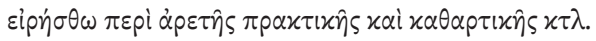


movements of the bodies that are in the heavens, also the consequences that follow from them, adopting throughout the same method and omitting all that was not really useful. For me this activity was my personal training'.11

In the Epitome, the selection of learned materials concerning logic and physics is based on the criteria of clarity and utility. Blemmydes' approach is consistent with the cultural milieu of his age, as is testified to by, among others, a passage from the proem of Joseph Rakendytes' Synopsis variarum disciplinarum. This latter scholar lived between 1260 and 1330, that is, in the years immediately after Blemmydes lifetime. ${ }^{12}$ His encyclopedic work is of particular interest because Rhakendytes borrowed entire passages not only from the Epitome, but from Blemmydes' opera omnia, often word for word. Blemmydes' passages were also expanded by inserting extracts from other treatises, for instance, from John of Damascus and George Pachymeres. ${ }^{13}$ In the proem, Rhakendytes explains the methodology he employed: ${ }^{14}$

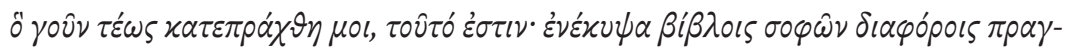

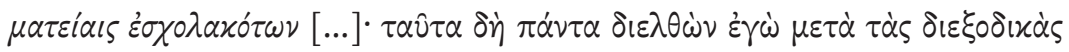

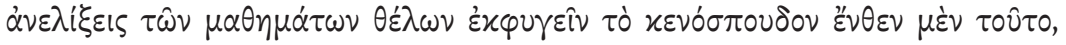

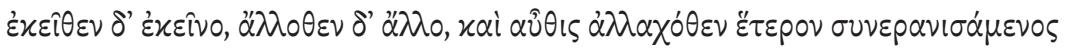

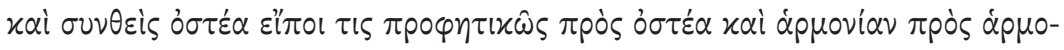

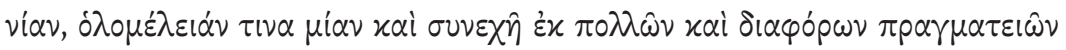

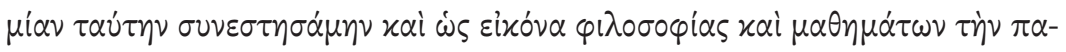

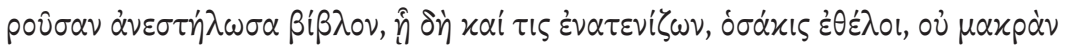

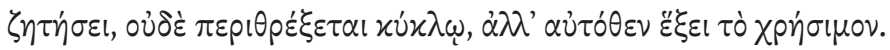

'This is what I have made so far: I studied books of wise men who had dealt with various topics [...]. I treated all these things in accordance with the detailed expositions of (each) discipline because I wanted to avoid what is worthless: I took over a point from one text, another from another one, again another from another one, and then again another from another one. Connecting bone to bone - to speak according to the prophet - and joint to joint, I put together from many different treatises

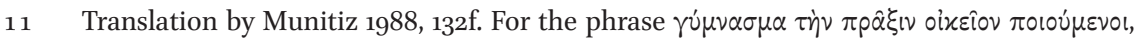

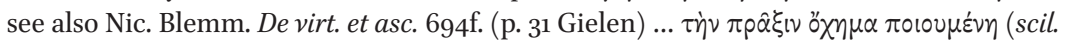

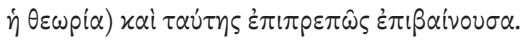

12 See Treu 1899; Gielen 2013, ead. 2016, LXXI-LXXIV with rich bibliography.

13 See Gielen 2016, LXXIV-LXXIX.

14 The Greek text is quoted according to Treu $1899,37,5$ f. and $24-32$. 
this present one, the result of which is uniform and coherent. Thus, I erected this book as a monument on a column, as a representation of philosophy and the sciences. Looking at it whenever one wants to, one will not search for long, or run around in vain, rather one will find what is useful promptly'

The prophet that Rhakendytes is alluding to is Ezekiel $(37,7)$, as Erika Gielen rightly stresses (2013, 266 n. 41):

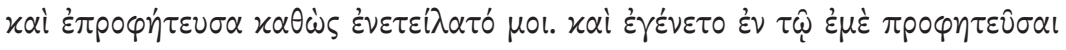

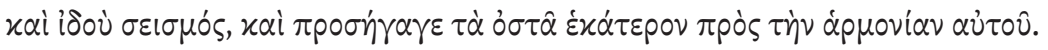

'So I prophesied as I was commanded: and while I prophesied, there was a shaking that put the bones together, each in its own place'.

The allusion is of particular relevance: just as the prophet rejoined and gave new life to the dispersed bones of the Israelites with the help of God, so Rhakendytes collected different treatises from well-defined sources and gave them new life in a new body, that is his Synopsis. For his part, Blemmydes adopted a similar methodology based upon the combination of different source texts, but on a more complex and refined level: he selected some passages from his source texts and copy-pasted them anonymously but in an original way, combining them for creating a new work. By doing this, the Aristotelian tradition was actively reinterpreted and updated. ${ }^{15}$

3. Wolfgang Lackner (1981) was the first scholar to systematically engaging the identification of the sources of Blemmydes' Compendium on Physics: ${ }^{16}$ Aristotle and his commentators, such as Simplicius, Philoponus and Alexander of Aphrodisia, constitute the core material, especially up to the middle of ch. 24

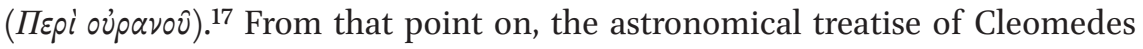
turns out to be the main source, in addition besides Aristotle. ${ }^{18}$ In this context,

15 See Valente 2017, 238, 246f. with further literature.

16 The identification of the source texts of the Epitome physica was initially undertaken by Wegelin 1606b. In the introduction to his Latin translation of the Epitome physica, he mentioned Plato, Aristotle and Cleomedes as the main sources (Praefatio pp. 2 and 4 [ = Patrologia Graeca 142, 1017f.) and added some references to those authors in the margin of the translation itself. (In the reprint of Wegelin's translation in the Patrologia Graeca, his marginal notes became footnotes).

17 For Blemmydes' use of Simplicius' commentaries, see Golitsis 2007. On Alexander of Aphrodisias in ch. 17, see Valente 2017.

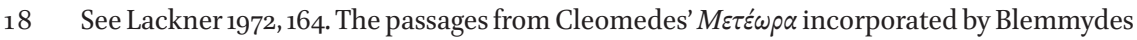
in the Epitome physica were collected by Todd 1990, 86. 
the introduction of Cleomedes, a Stoic philosopher, is particularly significant but, at the same time, is also quite typical for the early Palaeologan age, when there was a revival of his astronomic treatise. ${ }^{19}$ Moreover, occasional excerpts from other source works can be identified thanks to verbatim citations. In order to illustrate this methodology, ${ }^{20}$ I will discuss some examples from the Epitome physica, as the Vatican manuscript allows us to compare different compositional stages of the compendium.

Let us consider the incipit of ch. 31, dedicated to the concept of 'void' (Пвpi

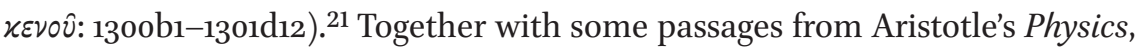
Book 4 (6-9, 213a12-217b28), Blemmydes' main source is Cleomedes. As is often the case, Aristotle inspires the beginning of the chapter. In the following table, Blemmydes' sources are quoted in the left column, the Vatican version of the Epitome is printed in the middle, the final version on the right: ${ }^{22}$

\section{Sources}

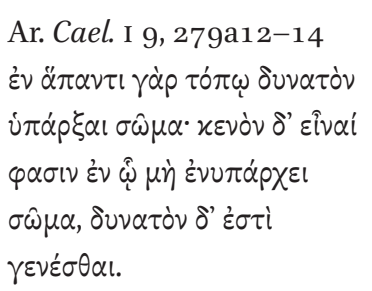

Ar. Ph. IV 1, 208b25-27

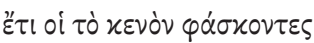

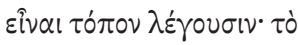

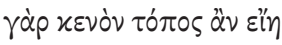

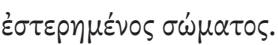

\section{Vat. gr. 434: Epitome \\ physica, first version}

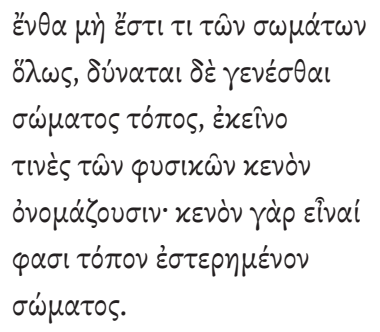

Epitome physica, final version (130ob2-6)

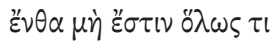

$\tau \hat{\omega} \nu \sigma \omega \mu \alpha \dot{\alpha} \tau \omega \nu, \delta \dot{v} \nu \alpha \tau \alpha\llcorner\delta \dot{\varepsilon}$

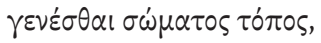

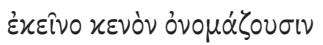

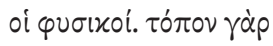

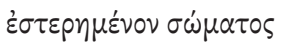

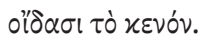

The first sentence of this chapter contains a general definition of 'void': according to Bydén's paraphrase $(2003,163)$, 'the natural philosophers call void a place where there is no body, but a body can be (place deprived of body)'. This

\footnotetext{
19 See e.g. Todd 1990, XXIX.

20 See also Golitsis $2007,244-246$ (on ch. 1), 246-248 (on ch. 4), 248-251 (on ch. 7), 251f. (on ch. 9); Valente 2017, 234-246 for an analysis of ch. 17, its sources and the methodology of compilation.

21 Bydén 2003, 163-168 studied this chapter in detail.

22 Following the suggestion of an anonymous peer reviewer, I have changed the Byzantine punctuation and accentuation of the Vatican manuscript (and of the final version of the Epitome) here and below, according to the conventions used for classical texts.
} 
beginning seems to result from the combination of two Aristotelian passages, one from the treatise De caelo, the other from Physics. ${ }^{23}$ The relevant information has been selected, reworked and simplified. In this case, the final redaction of the Epitome shows only stylistic changes.

Immediately after this sentence, Blemmydes added a doxographic digression, including Christian content, while revising his treatise. In fact, the following passage is not present in the Vaticanus, but in all the manuscripts of the final version $\left(1300 b_{7}-\mathrm{c} 2\right)$ :

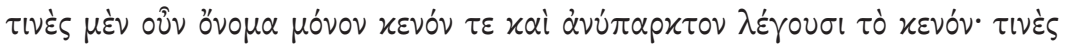

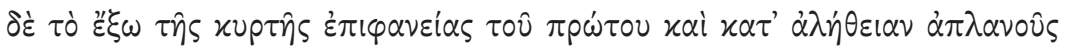

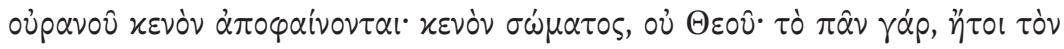

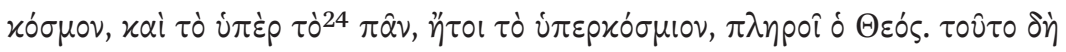

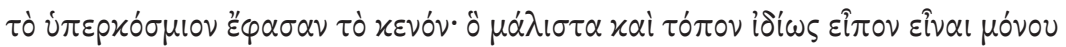

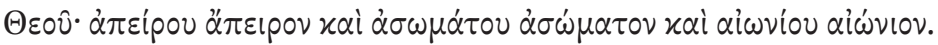

'So, some say that void is just a void and non-existent name. Others assert that what is beyond the convex surface of the first and truly fixed heaven is void: i.e. void of body, not of God, since God fills the Whole, that is the Cosmos, and what is beyond the Whole, that is what is beyond the Cosmos. They called this supramundane void, and they said that it is indeed the place especially and uniquely designated for God, an infinite, incorporeal, and eternal place for an infinite, incorporeal, and eternal God.' 25

The source of this doctrine is still unknown. ${ }^{26}$ It may be an addition by Blemmydes himself, at least with respect to the theological part. ${ }^{27}$ As Bydén $(2003,164)$ remarks, "[...] he [scil. Blemmydes] tries to show (EP 31.2) that extracosmic void is consistent with Christian faith [...]. My efforts to trace a Patristic source of the statement reported in EP 31.2 have been in vain". ${ }^{28}$

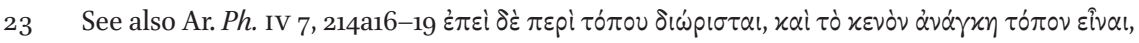

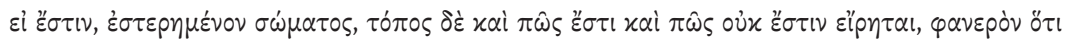

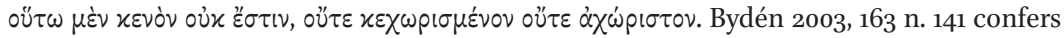
Ar. Ph. IV 6, 213b30-34 and Cleom. I 1,20-24.

24 The article $\tau$ ò is missing in the printed edition by Wegelin, but it is unanimously transmitted in the manuscripts.

25 Translation by Bydén 2003, 163 with some changes.

26 See also Bydén 2003, 163 with n. 142.

27 On this point, see Lackner 1981, $357 \mathrm{ff}$.

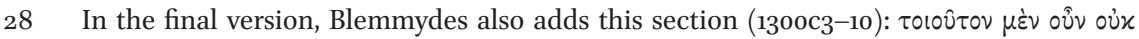

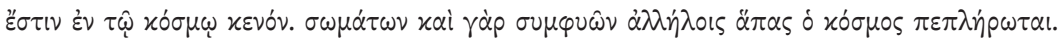

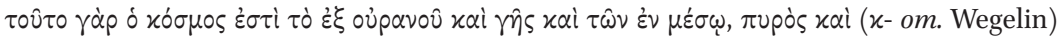


Cleomedes appears to be the main source for the remainder of this chapter. ${ }^{29}$ The following $\S \S 3$ f. (130oc11-d11) offer a good example for visualizing how the source text is used and reshaped. The absence of void within the Cosmos is rejected on the basis of the phenomena:

\section{Source: Cleom. I 1,68-78 Todd}

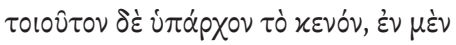

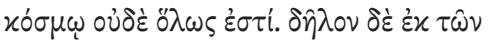

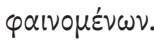

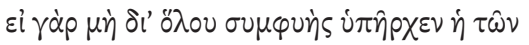

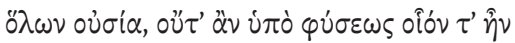

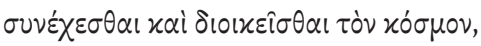

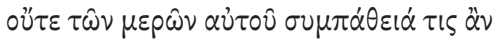

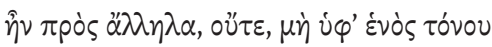

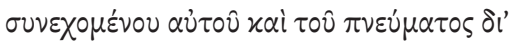

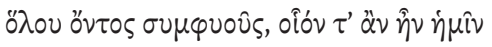

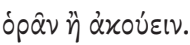

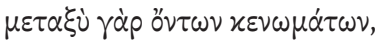

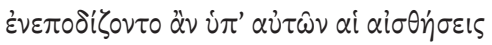
$x \tau \lambda$.

\section{Vat. gr. 434: Epitome physica, first version ${ }^{30}$}

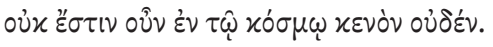

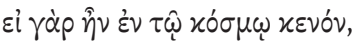

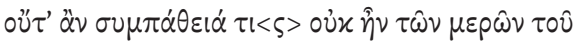

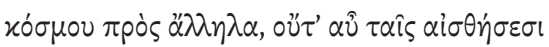

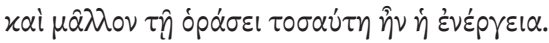

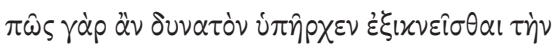

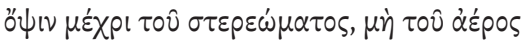

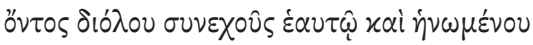

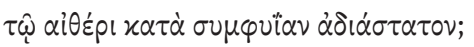

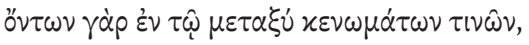

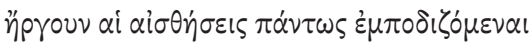

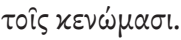

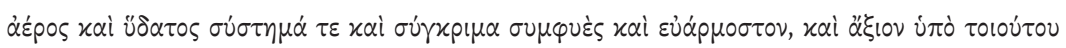

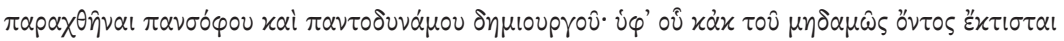
xai $\delta 1 \alpha x \varepsilon x o ́ \sigma \mu \eta \tau \alpha$. See Bydén 2003, 163 (with nn. 143f.): "Such a kind of void does not exist within the world. For the latter is entirely filled by a continuum of bodies. For this is the world: a continuous, well-fitted system of heaven, earth and the things in between, fire, air and water, such as is worthy of being created by an omniscient and omnipotent Creator, who created it out of nothing". See also Psellos' treatise $\Pi \varepsilon p i \tau \hat{\omega} \nu i \delta \varepsilon \omega \hat{\nu} \alpha \dot{\varsigma} \zeta \lambda \dot{\alpha} \tau \omega \nu$

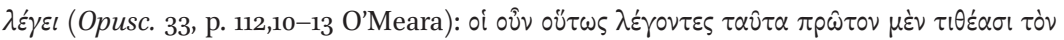

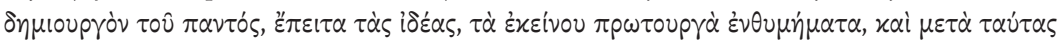

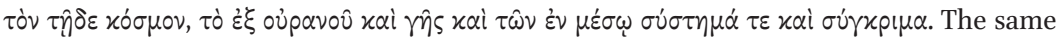

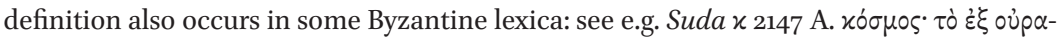

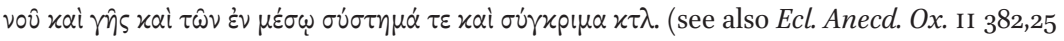

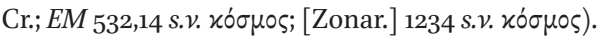

29 See Wegelin 16o6, 368 (= PG 1421299 n. 30); Todd 1990, 86; Bydén 2003, 163f. with nn. 143-147.

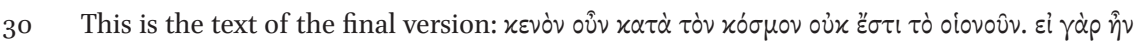

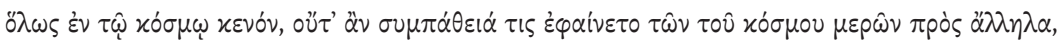




\section{Source: Cleom. I 1,68-78 Todd}

'Since the void exists in this way, it is also not present at all within the cosmos. This is clear from the phenomena.

For if the substance of the whole cosmos were not naturally linked throughout, then: $(a)$ the cosmos could neither be held together and administered throughout by Nature, nor could its parts have any sympathy relative to one another; $(b)$ we would also be incapable of seeing and hearing, if the cosmos were not held together by a single tension (that is, if the pneuma were not naturally linked throughout); for if there were intervening void spaces, our senses would be impeded by them (etc.). ${ }^{31}$

\section{Vat. gr. 434: Epitome physica, first version}

'So it is not possible that void is present in the cosmos.

For if there were void in the cosmos, there would not be any sympathy relative to one another nor, furthermore, the perceptions, and particularly sight, would not be active. In fact, how would it be possible for the eyes to reach the firmament if the air were not a continuous connection in itself and united to the heaven through an uninterrupted natural continuity. For if there were intervening void spaces, our senses would be inactive and impeded by the void spaces'. ${ }^{32}$

These passages reveal that Blemmydes usually adopts the text of his source, sometimes changing the wording, sometimes simply reproducing it verbatim. Furthermore, he also expands the source text in order to better explain his own opinions. For instance, in this last passage, Cleomedes introduces the examples of seeing and hearing to clarify what would happen in case of void, while Blemmydes concentrates only on seeing, explaining the consequences the void would cause if it existed, i.e. the impossibility of perceiving the firmament. Such an innovation is likely due to Blemmydes' aim to offer a clearer exemplification to the users of his philosophical compendium.

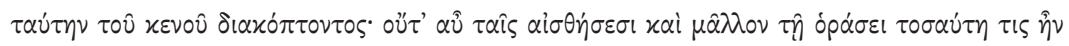

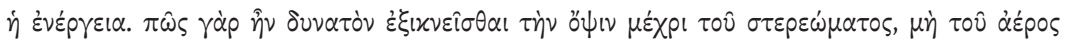

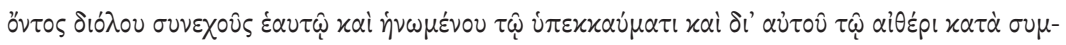

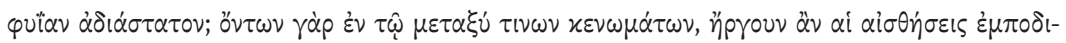

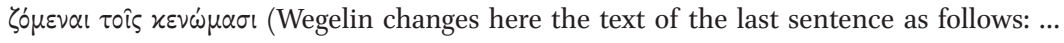

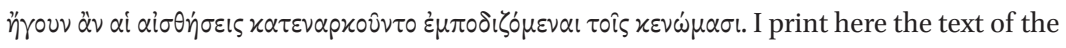
manuscripts).

31 Transl. Bowen-Todd 2004, 25f.

32 My translation takes account of those by Bowen-Todd 2004, 25f. and Bydén 2003, 163. 
4. In general, the Vatican redaction is closer to the wording of the sources than the final version of the Epitome. ${ }^{33}$ It is therefore essential for understanding Blemmydes' relationship with - and use of - his sources. Moreover, it is also fundamental in some other cases, in which the presence of marginal annotations allows us to imagine the workshop of the author. For example, let

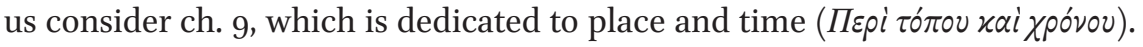
In the Vaticanus, the beginning of this chapter deals with the explanation of

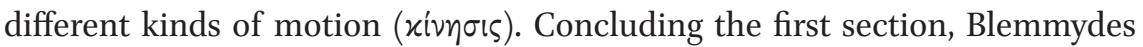
writes (cf. 1100a11-b2):

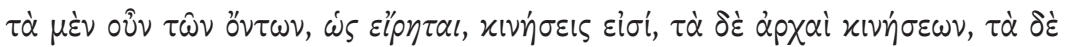

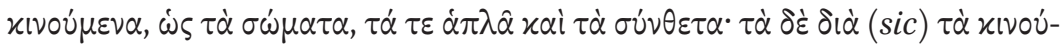

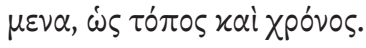

'So, as it has been said, some of the things that are are motions, some others are origins of motions, some others are things being moved (such as bodies both simple and compound), some others are through [sic] things being moved ( such as space and time)'. ${ }^{34}$

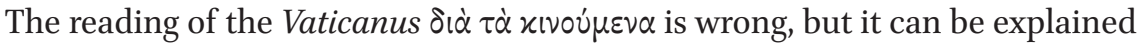
on the basis of the source of this passage, in this case Simplicius' commentary on Aristotle's Physics (CAG IX 397,15-18 Diels):

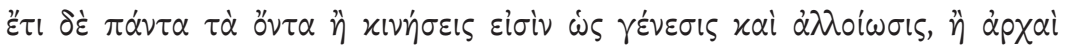

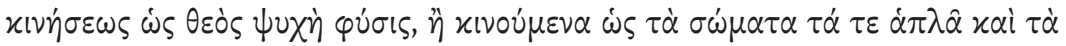

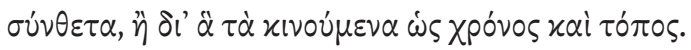

'Also all the things that there are are either motions, such as coming to be and alteration, or are origins of motions, such as god, soul and nature, or things being moved, such as bodies both simple and compound, or the media of their change, such as time and place'. ${ }^{35}$

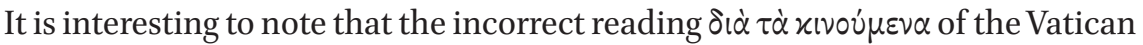
manuscript is also shared by the ms. Marcianus gr. Z. 227 (end of 13th century), which transmits Simplicius' commentary, as Hermann Diels reports in his critical apparatus. Furthermore, this is the common reading of all the manuscripts

33 See Lackner 1981; Valente 2017, 235-238.

34 My translation takes that by Urmson 2002, 14 into account.

35 Transl. Urmson 2002, 14 with few changes. 
with the final redaction of the Epitome physica: it must therefore be considered as the original text written by the author, even if it is wrong. The mistake can be ascribed to the manuscript source used by Blemmydes when compiling his compendium. ${ }^{36}$

Moreover, in the margin of the above mentioned passage of ch. 9, the Vaticanus transmits the following note, written in red ink (fol. $169^{\mathrm{r}}$ ):

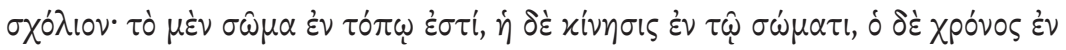

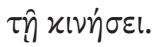

'Comment: the body is in a place, the motion in the body, the time in the motion'.

In all the manuscripts of the final version of the Epitome physica, this marginal note appears as main text. ${ }^{37}$ It is likely that this sentence originates from an addition made by Blemmydes himself to the text of the first redaction of the compendium. When revising it, he possibly considered this remark as necessary and thus added it. In fact, in the final redaction, the marginal note of the Vaticanus appears in the main text, introduced by a connective particle ơ̂v (110oa11-b2, § 1):

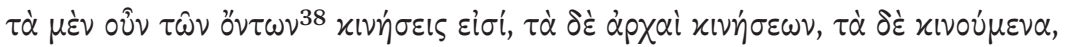

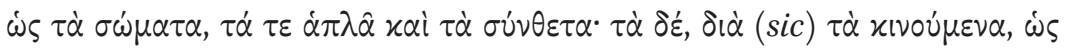

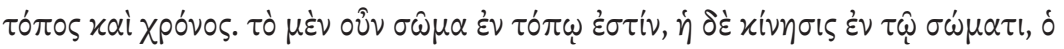

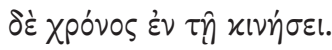

Another marginal note in the Vaticanus is of pivotal importance for identifying a source for a given passage and thus for understanding Blemmydes' working methodology. The case in point is in ch. $27(\S 7)$, which deals with the Moon

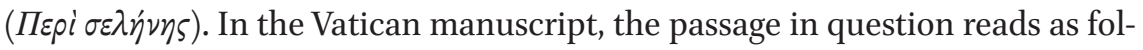
low (fol. $\left.193^{\mathrm{r}-\mathrm{v}}\right)$ :

36 For similar cases, see Golitsis 2007, 252-256.

37 As the notation $\sigma \chi 0$ '́ $10 \mathrm{v}$ indicates, this note should not be interpreted as a correction by the scribe in order to supplement a sentence that he had skipped while copying the main text: in such cases, he uses the conventional abbreviation $x \varepsilon i(\mu \varepsilon v \circ v)$ or just a sign linking the addition in the margin to the right place in the text.

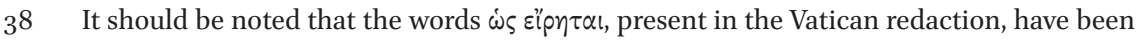
suppressed. 


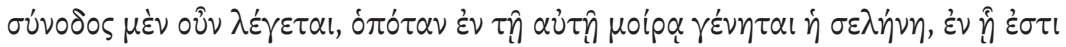

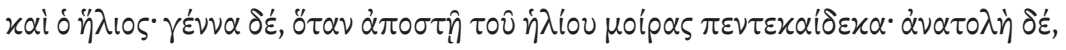

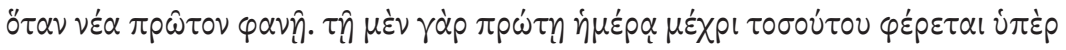

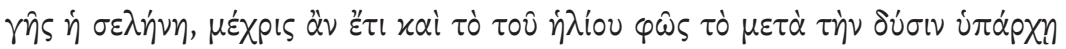

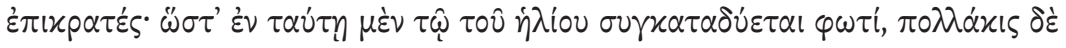

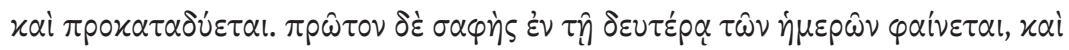

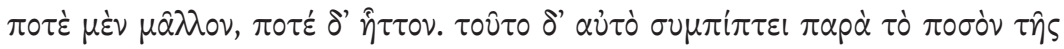

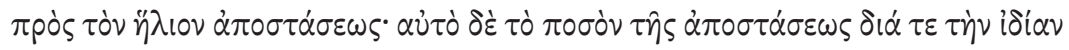

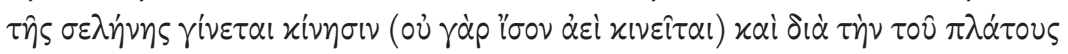

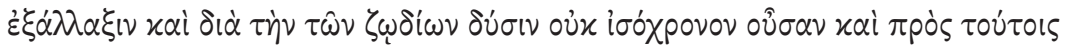

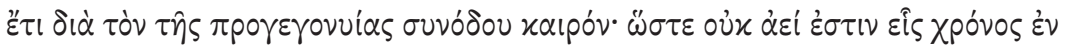

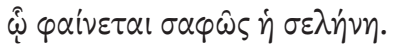

'Conjunction (sýnodos) is therefore said to be when the Moon is located at the same degree as that of the Sun; coming forth (génna), when it is at a distance of 15 degrees from the Sun; first appearance (anatolé), when it appears new for the first time. On the first day, the Moon moves over the Earth until the moment when the light of the Sun, after setting, still prevails, so that the Moon sets on this day together with the light of the Sun, but it often sets before this. The Moon appears bright for the first time on the second day, sometimes more, sometimes less. And this very thing happens in respect to the measure of the distance from the Sun. The measure itself of the distance is a consequence (i) of the Moon's own movement (in fact, it does not always move in the same way), (ii) of the change of the orbit, (iii) of the setting of the signs of the Zodiac, which does not always happen in the same time, (iv) of the moment of the conjunction that occurred before. Therefore, there is not always only one time when the Moon appears bright'.

The source of the first sentence is a passage on the lunar phases from John

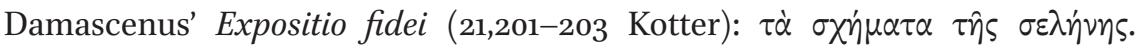

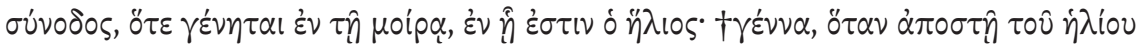

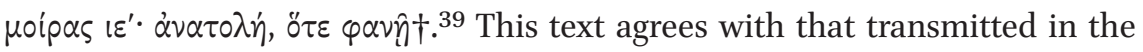
Vatican manuscript. However, Kotter considers it erroneous on this basis (app.

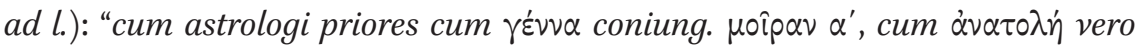

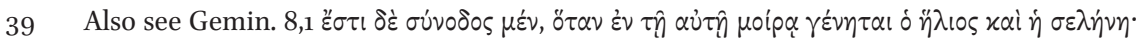

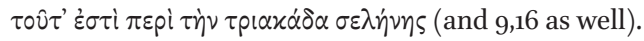




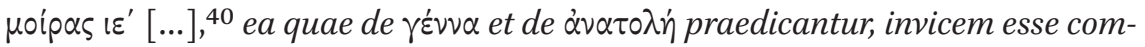

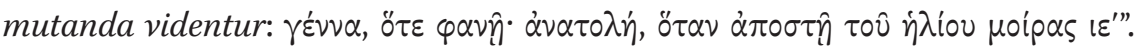
Blemmydes must have found this error in the manuscript he used, while compiling this passage. Nonetheless, he changed later the text as follows (126od9-

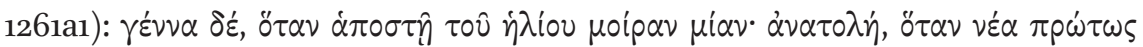
$\varphi \alpha v \eta{ }^{41}$ We can surmise that Blemmydes probably consulted a different source when doing this. ${ }^{42}$

Concerning the following part of the passage quoted above, the Vaticanus transmits a precious piece of information in the margin:

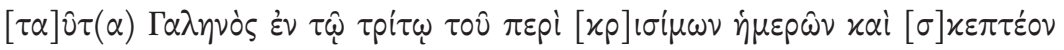 \\ $\pi \varepsilon p i \alpha$ ¿ $\tau \omega \mathrm{\nu}$.
}

'Galen writes these things in the third book of De diebus decretoriis and one should consider them with attention'.

40 Here, Kotter quotes an excerpt from the treatise De natura planetarum of Rhetorius (in turn based upon Vettius Valens) as transmitted in ms. Berol. Phill. 1577 (Boll 1908, 223,25-

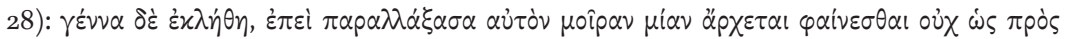

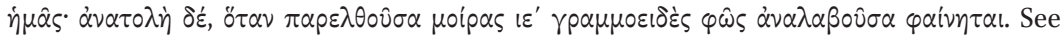
also below, n. 42 .

41 This is the complete text of the final version of the passage discussed here as it appears in the editio princeps by Wegelin (126od7-1261b5; I also indicate two omissions in the Greek text on the basis of my research on the text of the Epitome physica): $\sigma \dot{v} v 0 \delta 0 \varsigma \mu \varepsilon \dot{v}$ oûv $\lambda \varepsilon \dot{\varepsilon} \varepsilon-$

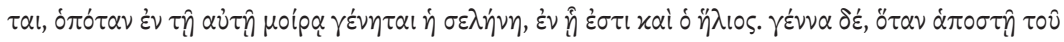

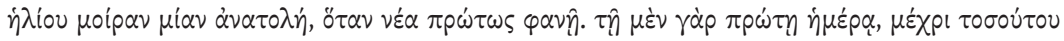

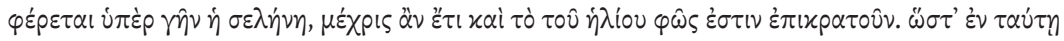

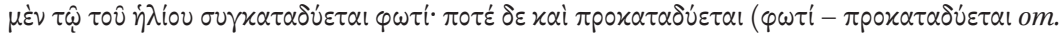

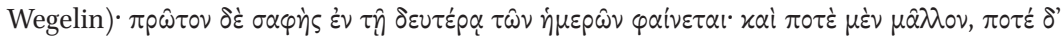

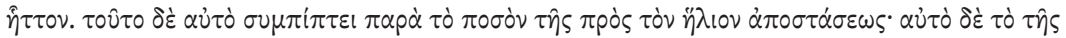

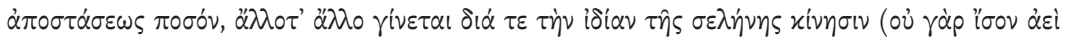

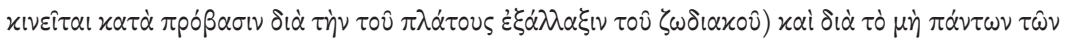

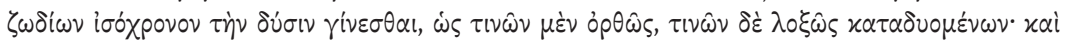

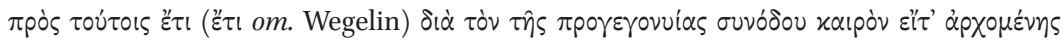

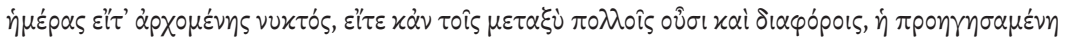

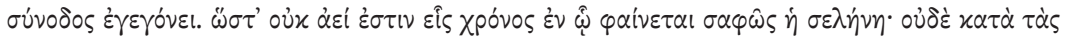

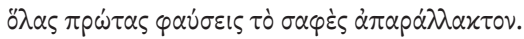

42 At this point in the research, the exact source has not yet been identified. For instance,

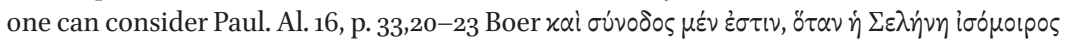

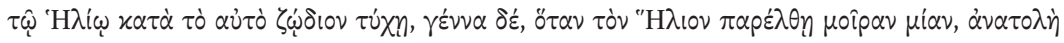

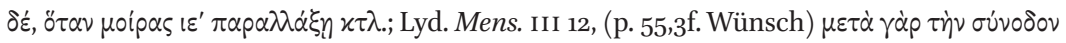

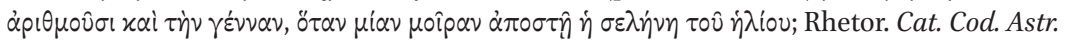

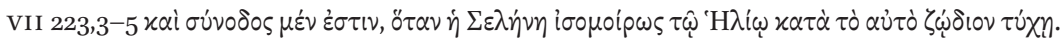

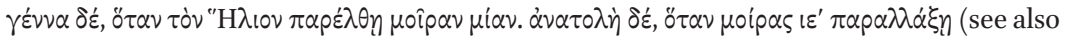
above, n. 40). 
In this marginal note, a passage of Galen's De diebus decretoriis is identified as the direct source (the relevant sentences are in italics):

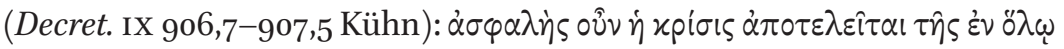

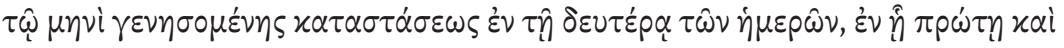

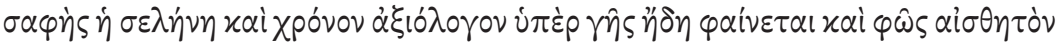

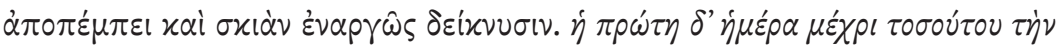

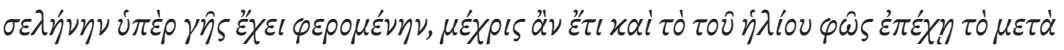

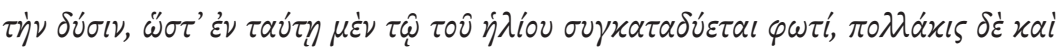

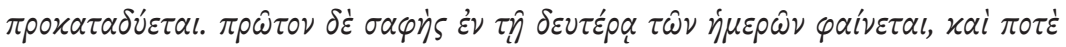

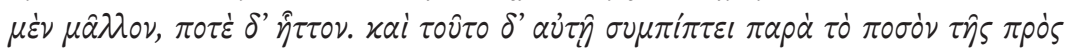

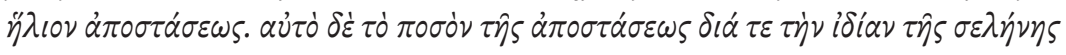

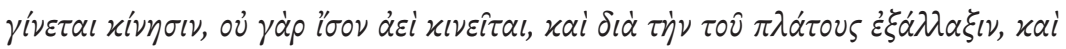

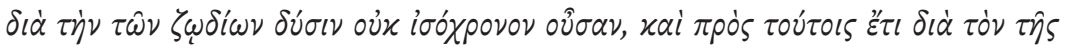

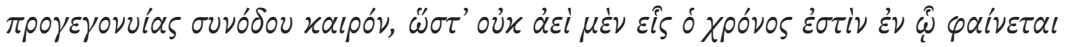
$\sigma \alpha \varphi \omega \hat{\varsigma} \dot{\eta} \sigma \varepsilon \lambda \dot{\eta} \nu \eta$.

'The judgement regarding the condition for the whole month is forecasted with certainty on the second day, when the Moon is also clear on the first one, shines for a remarkable length of time over the Earth, sends a perceptible light and clearly shows a shadow. The first day has the Moon moving over the Earth until the moment when the light of the Sun, after setting, still prevails, so that the Moon sets on this day together with the light of the Sun, but it often sets before this. The Moon appears bright for the first time on the second day, sometimes more, sometimes less. And this happens to the Moon in respect to the measure of the distance from the Sun. The measure itself of the distance is a consequence ( $i$ ) of the Moon's own movement (in fact, it does not move always in the same way), (ii) of the change of the orbit, (iii) of the setting of the signs of the Zodiac, which does not always happen in the same time, (iv) of the moment of the conjunction that occurred before. Therefore, there is not always only one time when the Moon appears bright.

With regard to Galen, it should be recalled that Blemmydes practised the profession of medicine for seven years when he was young, between 1214 and $1221 .{ }^{43}$

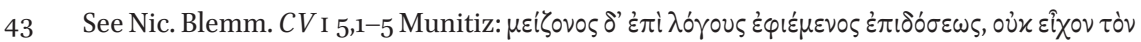

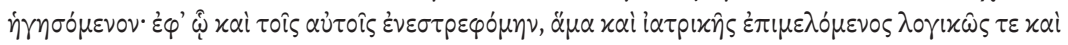

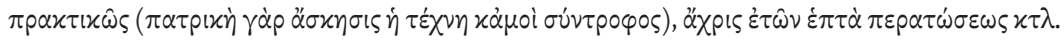
For this passage, see Munitiz 1988, 15, 44. 
It is likely, therefore, that he had first-hand knowledge of the medical treatise by Galen. He also mentions the princeps medicorum in some passages of both the Epitome ${ }^{44}$ and of his treatise De corpore. ${ }^{45}$ Furthermore, in relation to the marginal note in the Vaticanus, the precise indication of the source is striking. Even we cannot exclude the possibility of a reader who was well-versed in medical literature identifying the source of this passage in Blemmydes' compendium and writing it down in the margin of his own manuscript - be it the Vaticanus itself or its exemplar - it may be the easiest solution to attribute this marginal note to the author himself, or to one of his pupils. Since this manuscript may thus represent quite a reliable copy of a working manuscript with the first redaction of the Epitome physica, it offers precious details for understanding how this Byzantine philosophical compendium was composed and structured.

5. In conclusion, Blemmydes' Epitome physica is an original work within the Byzantine Aristotelianism of the 13th century. The author enriched this tradition, based upon Aristotle and his commentators, using different works, such as Cleomedes' astronomical treatise, Galen, and John of Damascus. On this basis, Blemmydes composed a handbook to support his teaching activities. This work underwent different stages of revision, and can be considered a 'work in progress', until the author produced a final version in the last years of his life. The success of his Epitome as a philosophical textbook can be measured, in particular, on the basis of the number of surviving manuscripts (more than hundred): the oldest codices date to few decades after Blemmydes' death, a huge number was produced during the Italian Renaissance, while the last exemplars were copied in Greece and Romania between the 18th and 19th centuries. ${ }^{46}$ Thus, Blemmydes' Epitome has significantly contributed to the spread of Greek-Byzantine thought over the centuries, and is an accomplished example of a compendium for teaching and learning (mainly) Aristotelian philosophy.

\section{Acknowledgements}

This paper was conceived within the project Wissenschaft und Naturphilosophie in der byzantinischen Welt: Das Physiklehrbuch des Nikephoros Blemmydes,

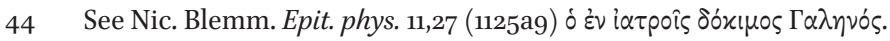

45 The only available edition is that by D. Boulesmas, printed in Leipzig 1784 (vol. III, pp. 1-29).

46 See also Valente 2016, 279f.
} 
funded by the Deutsche Forschungsgemeinschaft at the University of Hamburg. It represents a revised version of the talk given on the occasion of the Neapolitan conference Per commentaria docere. I would like to thank once again Tommaso Raiola and Amneris Roselli for their invitation. I also thank Tiziano Dorandi, Rachele Pierini and Renzo Tosi for their comments on a first draft of this paper as well as the anonymous peer reviewer for their valuable remarks. All the translations are mine, unless otherwise indicated.

\section{Bibliography}

Angelov, D. (2012). Classifications of political philosophy and the concept of royal science in Byzantium. In: B. Bydén and K. Ierodiakonou (eds.), The Many Faces of Byzantine Philosophy, Athen, pp. 22-49.

Boll, F. (1908). Catalogus codicum astrologorum Graecorum, vir. Bruxelles.

Bydén, B. (2003). Theodore Metochites' Stoicheiosis astronomike and the Study of Natural Philosophy and Mathematics in Early Palaiologan Byzantium. Göteborg.

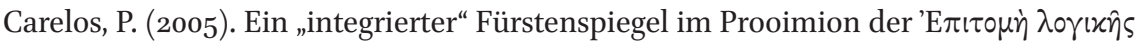
des Nikephoros Blemmydes. Byzantinische Zeitschrift 98, pp. 399-402.

Devreesse, R. (1937). Codices Vaticani Graeci, II. Rome.

Ebbesen, S. (1981). Commentators and commentaries on Aristotle's Sophistici Elenchi (...), I-III. Leiden.

Gielen, E. (2013). Ad maiorem Dei gloriam. Joseph Rhakendytes' synopsis of Byzantine learning. In: J. König and G. Woolf (eds.), Encyclopaedism from Antiquity to the Renaissance, Cambridge, pp. 259-276.

Gielen, E., ed. (2016). Nicephori Blemmydae De virtute et ascesi. Iosephi Rhacendytae De virtute. Turnhout.

Golitsis, P. (2007). Nicéphore Blemmyde lecteur du commentaire de Simplicius à la Physique d'Aristote. In: C. D'Ancona (ed.), The Libraries of the Neoplatonists, LeidenBoston, pp. 243-256.

Ierodiakonou, K. (2012). A Logical Joust in Nikephoros Blemmydes' Autobiography. In: J.L. Fink, H. Hansen and A.M. Mora-Marquez (eds.), Logic and Language in the Middle Ages. A Volume in Honour of Sten Ebbesen, Berlin-Boston, pp. 125-137.

Lackner, W. (1972).Zum Lehrbuch der Physik des Nikephoros Blemmydes. Byzantinische Forschungen 4, pp. 157-169.

Lackner, W. (1981). Die erste Auflage des Physiklehrbuches des Nikephoros Blemmydes. In: F. Paschke (ed.), Überlieferungsgeschichtliche Untersuchungen, Berlin, pp. $351-364$.

Munitiz, J. A. (1988). Nikephoros Blemmydes. A Partial Account. Introduction, translation and notes. Leuven. 


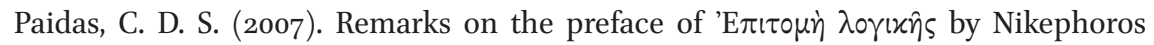

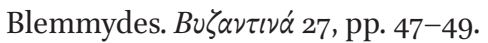

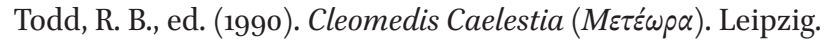

Treu, M. (1899). Der Philosoph Joseph. Byzantinische Zeitschrift 8, pp. 1-64.

Urmson, J. O., transl. (2002). Simplicius. On Aristotle Physics 3. London.

Valente, S. (2016). Die Werke des Nikephoros Blemmydes in der Manuskriptsammlung

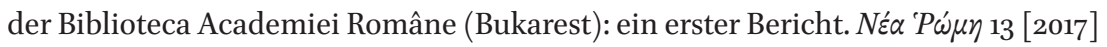

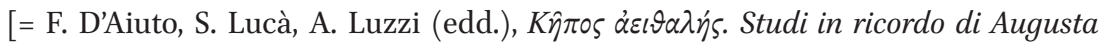
Acconcia Longo, I], pp. 277-286.

Valente, S. (2017). The Doctrine of Winds in Blemmydes: On the Reception of Aristotelian Meteorology in the Palaeologan Age. Greek, Roman, and Byzantine Studies 57, pp. 231-247.

Valente, S. (2018). Blemmydès, Nicéphore (39a). In: R. Goulet (éd.), Dictionnaire des philosophes antiques, VII, Paris, pp. 470-475.

Valente, S. (2019). Zur Überlieferung der Epitome physica des Nikephoros Blemmydes: die ältesten Handschriften. In: Ch. Brockmann, D. Deckers, D. Harlfinger and S. V. (eds.), Griechisch-byzantinische Handschriftenforschung. Traditionen, Entwicklungen, neue Wege, Berlin, pp. 519-527.

Wegelin, J., ed. (1606a). Nicephori Blemmidae Epitome physica (...). Augsburg.

Wegelin, J., ed. (1606b). Nicephori Blemmidae Epitome physica, Latine versa, \& brevi analysi singulorum capitum in certa membra, membrorumque argumentis, allegationibus item marginalibus \& notis alicubi aucta \& illustrata (...). Augsburg. 